\title{
Perancangan Media Pembelajaran Berbasis Aplikasi Android sebagai Penunjang Proses Belajar Kognitif pada Anak Autis di SLB
}

\author{
Faizal Fardani dan Sayatman \\ Departemen Desain Produk Industri, Institut Teknologi Sepuluh Nopember (ITS) \\ e-mail: sayatasik@gmail.com
}

\begin{abstract}
Abstrak - Anak penyandang autistme adalah salah satu dari anak berkebutuhan khusus. Karakteristik dari anak penyandang autisme adalah kekurangan dan ketertinggalan terhadap beberapa hal daripada anak normal, salah satunya ketertinggalan pada aspek kognitif. Kekurangan tersebut perlu diupayakan agar anak penyandang autisme dengan keterbatasannya dapat memenuhi kebutuhan dirinya secara otonom. Sehingga perancangan ini bertujuan untuk membantu mempermudah anak autis dalam melakukan proses belajar kognitif. Metode yang dilakukan dalam perancangan ini yaitu dengan melakukan observasi, wawancara sebagai data primer dan kajian penelitian sebagai data sekunder. Didapatkan beberapa fakta berupa kesulitan dan kebutuhan guru dan anak autis dalam melakukan proses pembelajaran. Fakta-fakta tersebut disusun dan dianalisa menjadi konsep desain berupa aplikasi yang memuat animasi dan pengulangan suara sebagai media pembelajaran dengan tujuan menjaga fokus anak autis dan memotivasi anak autis dalam melakukan pembelajaran. Perancangan ini menghasilkan luaran berupa aplikasi media pembelajaran untuk anak autis yang berisikan animasi dan review materi dengan pengulangan suara sebagai adaptasi dan strategi baru cara belajar pada anak autis untuk mempermudah anak autis dalam melakukan kegiatan pembelajaran kognitif. Oleh karena terancangnya aplikasi ini, diharapkan dapat memunculkan motivasi dan memaksimalkan fokus pada anak autis sehingga mampu memudahkan dan menunjang proses belajar kognitif pada anak autis.
\end{abstract}

Kata Kunci- Anak Autis, Aplikasi Android, Media Pembelajaran, Proses Belajar Kognitif.

\section{PENDAHULUAN}

$\mathrm{S}_{\mathrm{k}}^{\mathrm{A}}$ ALAH satu kasus yang banyak terjadi pada $18 \%$ angka kelahiran di Indonesia adalah anak-anak yang terlahir sebagai anak bekebutuhan khusus, diantaranya adalah anak penyandang autisme. Jumlah penyandang autisme di seluruh dunia terus mengalami peningkatan dari waktu ke waktu. Menurut penelitian yang dilakukan oleh Center for Diesease Control and Prevention di Amerika Serikat, jumlah penyandang autisme tahun 2015 mengalami peningkatan sebesar 23\% dibanding tahun 2008. Bila pada tahun 2008, 1 dari 100 anak mengalami gangguan spektrum autisme, maka pada tahun 2015, rasionya naik menjadi 1 dari 68 anak[1]. Sementara itu Pusat Data dan Statistik Pendidikan Indonesia mencatat pada tahun ajaran 2016/2017 jumlah siswa pendidikan luar biasa khusus kategori autisme di Indonesia berjumlah 10.785 jiwa[2]. Besarnya angka tersebut menunjukan bahwa autisme tidak hanya menjadi fenomena kecil yang terjadi di tengah-tengah masyarakat, lebih dari itu, bertambahnya prevelensi penderita autisme menunjukkan bahwa perlakuan dan penanganan khusus anak autisme sangat dibutuhkan.

Autisme sendiri merupakan gangguan yang meliputi area kognitif, emosi, perilaku, sosial, termasuk juga ketidakmampuan untuk berinteraksi dengan orang-orang di sekelilingnya. Anak yang autis akan tumbuh dan berkembang dengan cara yang berbeda dibandingkan dengan anak-anak normal lainnya[3].

Perilaku-perilaku yang menjadi keterbatasan bagi penyandang autisme tentunya harus diupayakan dan mendapatkan penanganan khusus agar anak penyandang autisme dengan keterbatasannya tersebut tetap dapat melakukan interaksi sosial. Dampak interaksi sosial yang mampu dilakukan oleh anak autisme akan membantu anak autisme memenuhi kebutuhan dirinya secara otonom[4].

Salah satu penanganan khusus untuk penyandang autisme adalah dengan dilakukannya intervensi pendidikan melalui SLB (Sekolah Luar Biasa). Seperti anak-anak normal yang lainnya, siswa SLB memiliki kemampuan intelektual. Kemampuan intelektual ini ada yang tinggi, sedang dan ada yang rendah. Kesulitan yang dialami siswa SLB yakni memiliki keterbatasan kemampuan sehingga sulit untuk dapat berkomunikasi. Kesulitan ini dapat menyebabkan menurunnya kemampuan intelektual dan dapat menyebabkan ketertinggalan dari sisi akademis dibandingkan dengan siswa lainnya yang normal. Untuk itu perlu dilaksanakannya upaya dan strategi untuk tetap mengembangkan potensi dan kemampuan intelektual siswa SLB salah satunya adalah anak autis[5].

Strategi pembelajaran yang digunakan dalam proses belajar untuk anak autis di SLB pada saat ini terbatas pada media flashcard. Media tersebut kurang berpengaruh jika digunakan sebagai media pembelajaran terhadap anak autis yang disebabkan kurang menariknya media tersebut untuk anak autis. Akibatnya fokus pembelajaran pada anak autis tidak dapat terjaga dan anak autis cenderung kembali fokus pada dunianya sendiri. Berdasarkan hasil observasi dan wawancara, anak autis lebih tertarik dan dapat fokus dengan jangka waktu yang cukup lama dengan digunakannya media audio-visual. Namun media audio-visual yang banyak beredar saat ini tidak memenuhi kriteria dalam pembelajaran anak autis dan tidak 


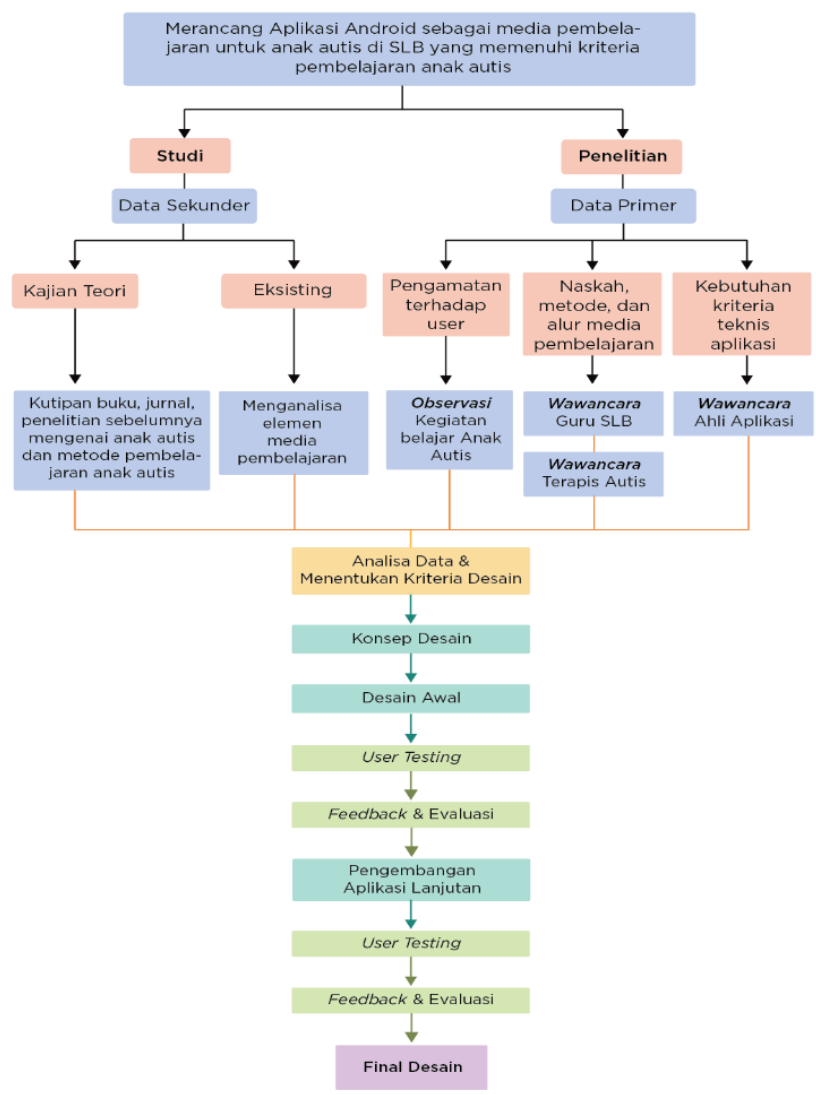

Gambar 1. Kerangka penelitian perancangan aplikasi media pembelajaran untuk anak autis.

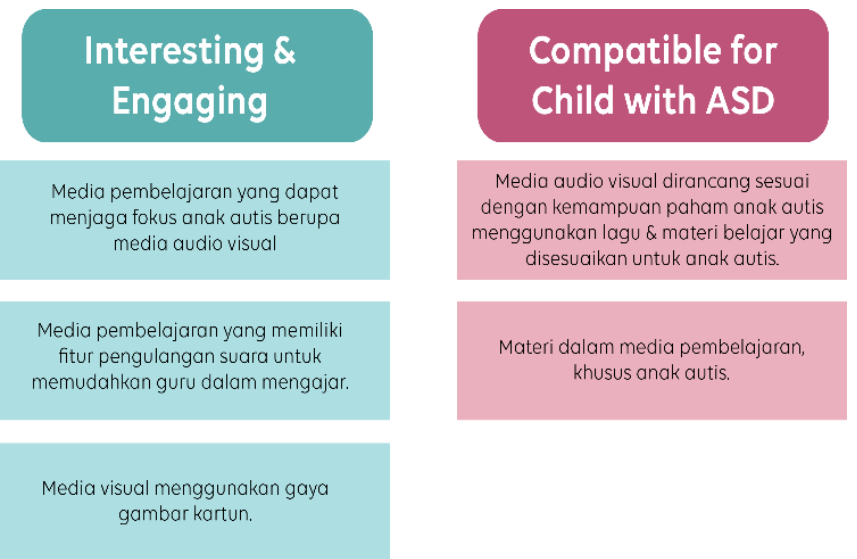

Gambar 2. Analisis dengan pengelompokkan berdasarkan isu sejenis.

dapat dipahami oleh anak autis.

Maka dari itu dibutuhkan sebuah media pembelajaran yang menarik untuk anak autis yang juga dapat dipahami oleh anak autis sehingga proses belajar dapat berjalan dengan efektif. Media pembelajaran tersebut dapat berupa aplikasi touchscreen pada android meninjau berdasarkan beberapa laporan penelitian, intervensi penggunaan teknologi memiliki potensi dalam meningkatkan efektifitas pembelajaran terhadap anak autis[6].

Fenomena-fenomena yang telah dijelaskan kemudian dijabarkan menjadi rumusan masalah. Rumusan masalah yang akan diselesaikan melalui perancangan ini adalah bagaimana merancang sebuah media pembelajaran berbasis aplikasi

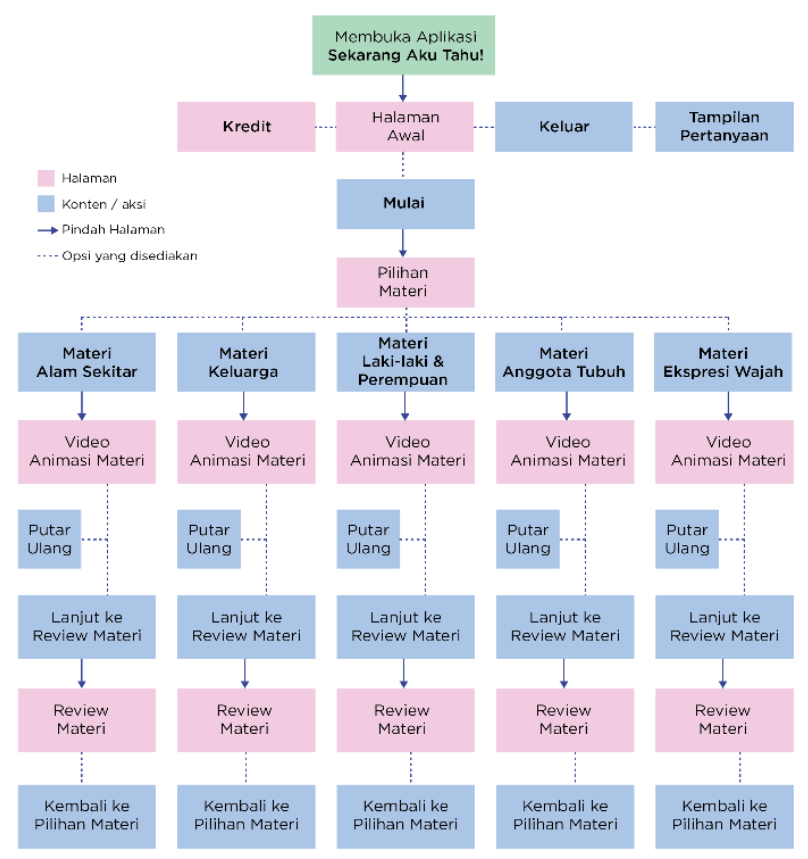

Gambar 3. Alur Arsitektur Informasi aplikasi.
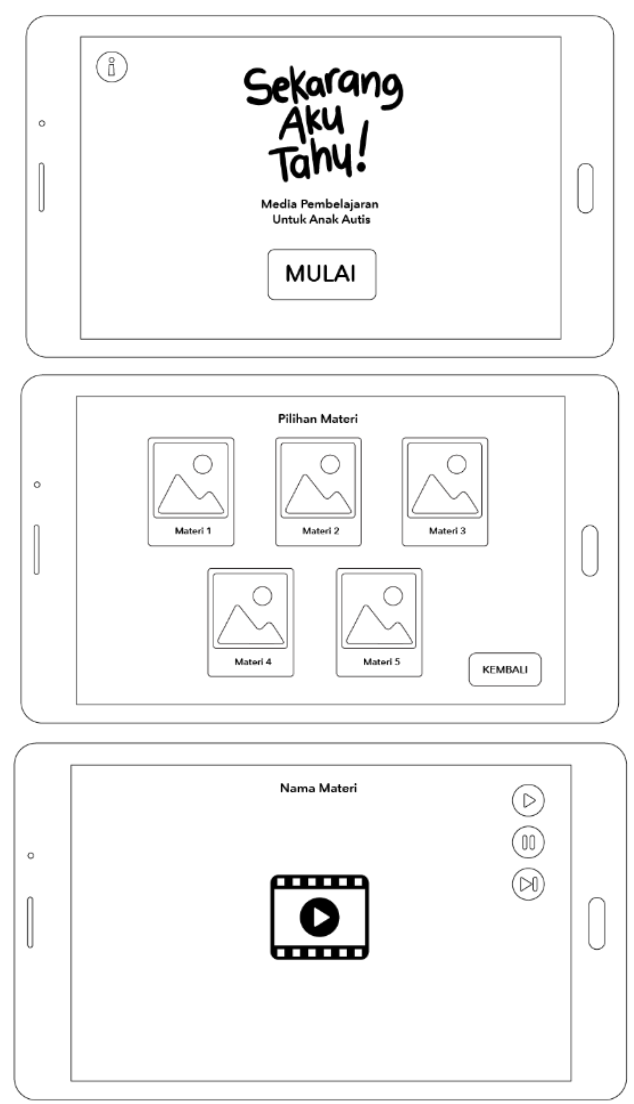

Gambar 4. Wireframe aplikasi.

android sebagai penunjang proses belajar kognitif pada anak autis di SLB. Perancangan ini akan membahas dan mengerjakan permasalahan yang berkaitan dengan media pembelajaran untuk anak autis berupa aplikasi android yang berisi media audio-visual berupa animasi dan fitur pengulangan suara.

Perancangan ini dilakukan dengan tujuan menciptakan 


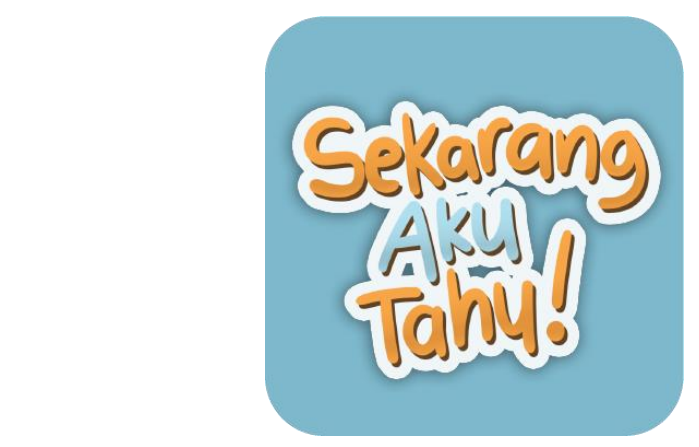

Gambar 5. Ikon produk aplikasi.

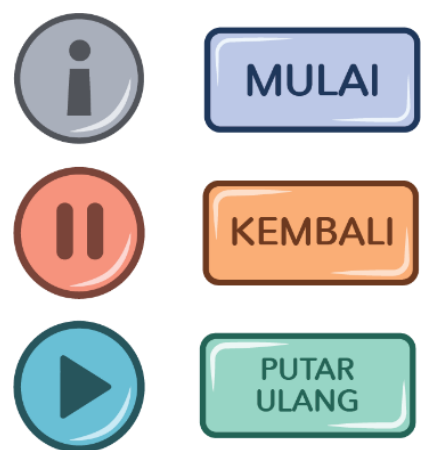

Gambar 6. Desain tombol pada aplikasi.
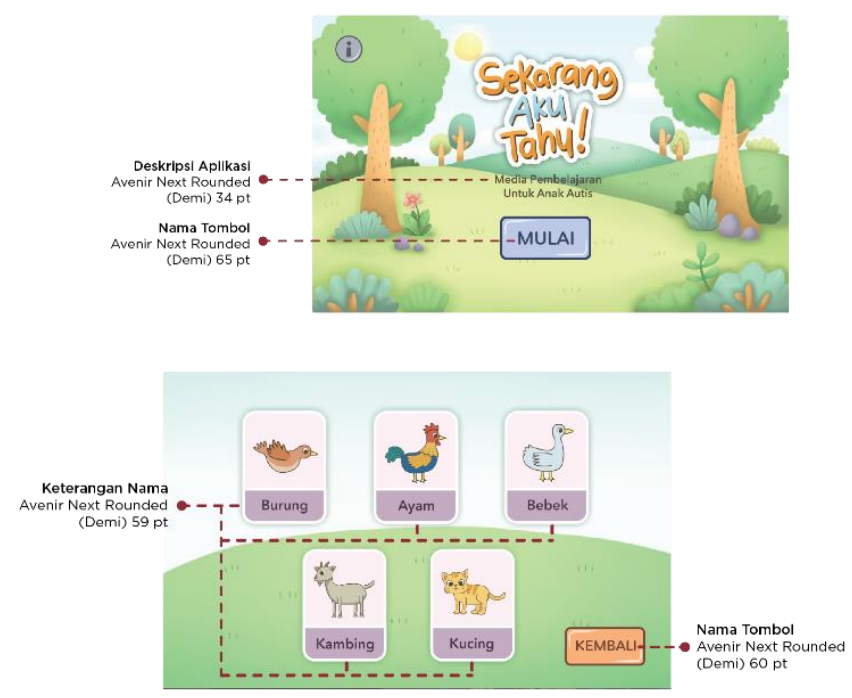

Gambar 7. Contoh implementasi ukuran dan jenis font.

aplikasi android sebagai media pembelajaran untuk anak autis di SLB yang memenuhi kriteria pembelajaran anak autis sehingga fokus dalam proses belajar pada anak autis dapat terjaga dan anak autis termotivasi dalam melakukan kegiatan belajar.

\section{METODOLOGI DAN ANALISIS PENELITIAN}

Berikut ini adalah alur penelitian dan proses desain dalam perancangan aplikasi media pembelajaran untuk anak autis yang dapat dilihat pada Gambar 1.
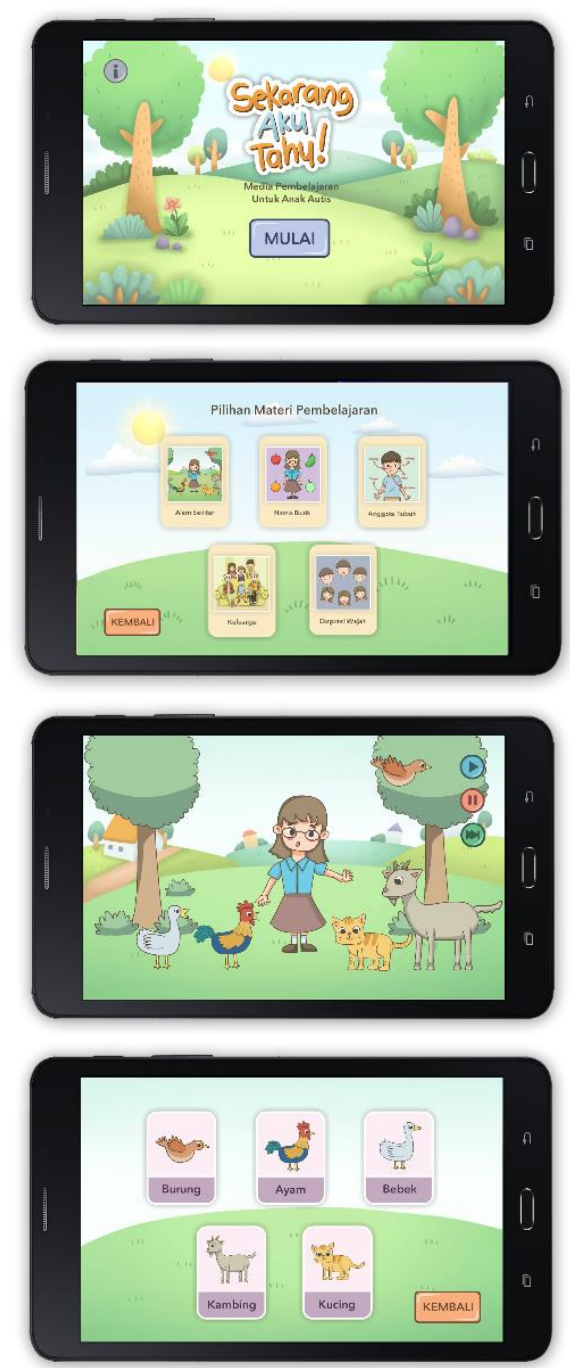

Gambar 8. Tampilan hasil akhir aplikasi dalam mock up tablet android 7 inchi.

\section{A. Metode Penelitian}

\section{1) Observasi}

Metode observasi dilakukan untuk mengetahui serta mendapatkan data dengan mendatangi sumber secara langsung. Metode ini diperlukan untuk memperoleh data mengenai sarana dan prasarana yang tersedia, serta kondisi lingkungan sekitar subjek penelitian. Hasil dari metode ini berupa foto, rekaman suara/gambar, dan catatan.

\section{2) Wawancara}

Metode wawancara ditujukan pada expert atau orang orang yang mengetahui mengenai seluk beluk kebutuhan perancangan. Untuk penentuan konten yang terdiri dari naskah, metode, dan alur media pembelajaran untuk anak autis dilakukan wawancara terhadap guru SLB Autistik, sedangkan untuk mengetahui kriteria kebutuhan teknis aplikasi dilakukan wawancara terhadap pakar aplikasi. Kegiatan wawancara dilaksanakan terhadap pengajar SLB Harapan Bunda. Hasil 


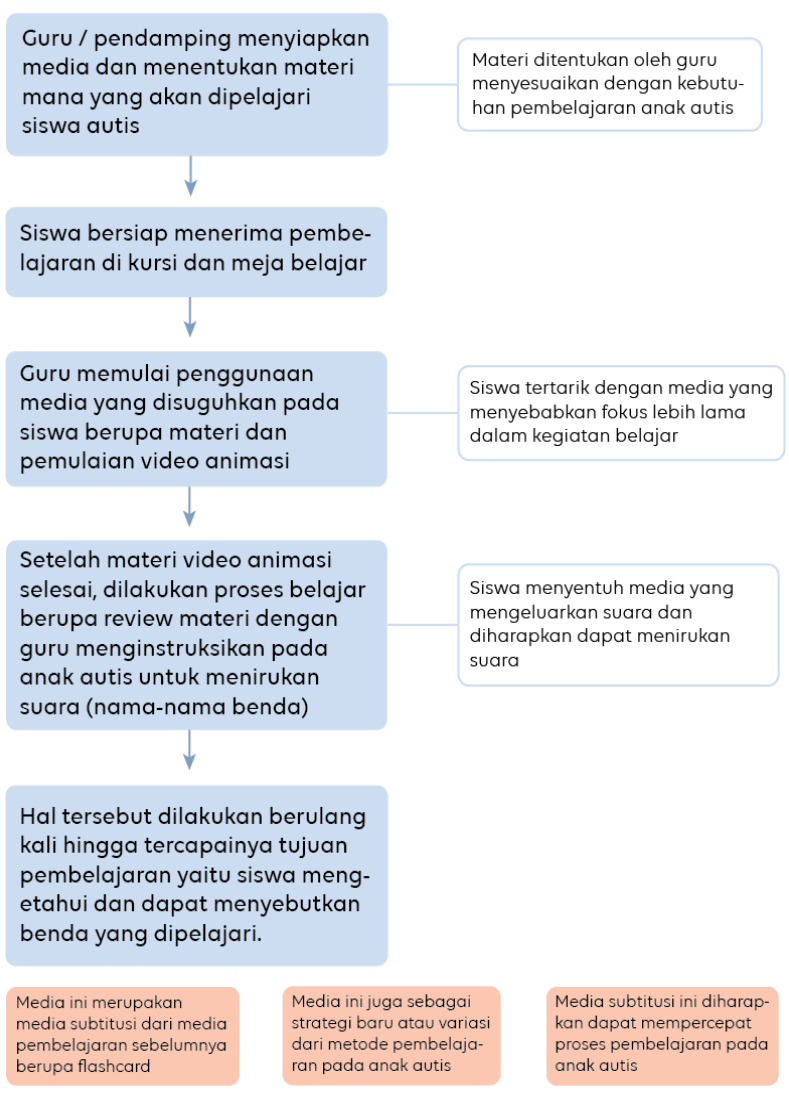

Gambar 9. Bagan skenario prosedur pengunaan media.

akhir dari metode ini adalah untuk mendapatkan data primer yang akan diolah pada analisa kebutuhan \& kriteria desain.

3) Studi Literatur

Studi literatur dilakukan untuk mengetahui dan mempelajari mengenai penelitian sebelumnya yang berkaitan dengan perancangan. Dengan mempelajari penelitian sebelumnya dapat diketahui landasan-landasan dan fakta-fakta mengenai kebutuhan dan cara belajar anak autis berdasarkan penelitian yang telah dilakukan. Dengan demikian penelitian yang dilakukan dapat terpandu dengan jelas dan tidak meraba-raba tanpa landasan.

\section{4) User Testing}

Metode User Testing dilakukan dengan tujuan untuk mengevaluasi purwarupa aplikasi yang dirancang. Evaluasi meliputi kemudahan pengguna (dalam hal ini guru SLB dan anak autis di SLB) dalam menggunakan secara intuitif dan efektifitas keterpengaruhan aplikasi terhadap cara belajar anak autis.

\section{B. Analisis Penelitian}

Dari metode-metode yang telah dilakukan didapatkan datadata berupa data primer dan data sekunder. Data-data tersebut kemudian dianalisa untuk ditemukan pokok-pokok fakta yang mendasari perancangan. Pokok-pokok fakta tersebut yang kemudian menjadi kriteria desain perancangan.

Pokok-pokok fakta tersebut jika dirangkum menjadi beberapa kebutuhan subyek perancangan dan solusi yang dapat ditawarkan oleh penulis. Beberapa pokok-pokok fakta tersebut
Tabel 1.

Skala indikator ketercapaian penggunaan media buku bergambar

\begin{tabular}{lr}
\hline \hline \multicolumn{1}{c}{ Indikator } & $\begin{array}{c}\text { Rata-rata } \\
\text { Nilai }\end{array}$ \\
\hline Ketertarikan anak & 2,5 \\
Ketermotivasian anak & 2,25 \\
Lama fokus pada anak autis (dalam detik) & 4,3 \\
Pemahaman anak autis & 2,75 \\
Pertambahan perkembangan kognitif & 2 \\
\hline \hline
\end{tabular}

Tabel 2.

Skala indikator ketercapaian penggunaan media flashcard

\begin{tabular}{lr}
\hline \hline \multicolumn{1}{c}{ Indikator } & $\begin{array}{c}\text { Rata-rata } \\
\text { Nilai }\end{array}$ \\
\hline Ketertarikan anak & 4,25 \\
Ketermotivasian anak & 2 \\
Lama fokus pada anak autis (dalam detik) & 4,65 \\
Pemahaman anak autis & 4,75 \\
Pertambahan perkembangan kognitif & 4,25 \\
\hline \hline
\end{tabular}

Tabel 3.

Skala indikator ketercapaian penggunaan media aplikasi

\begin{tabular}{lr}
\hline \hline \multicolumn{1}{c}{ Indikator } & Rata-rata \\
& Nilai \\
\hline Ketertarikan anak & 8 \\
Ketermotivasian anak & 6,25 \\
Lama fokus pada anak autis (dalam detik) & 7,85 \\
Pemahaman anak autis & 5,25 \\
Pertambahan perkembangan kognitif & 6 \\
\hline \hline
\end{tabular}

diantaranya:

- Penggunaan media pembelajaran yang sudah ada berupa flashcard susah dalam membuat anak autis menjadi fokus dalam melakukan kegiatan belajar.

Kebutuhan: Media pembelajaran baru yang dapat mendapat guru untuk menjaga fokus anak autis.

Solusi yang ditawarkan penulis: Media pembelajaran yang dapat menjaga fokus anak autis berupa media audio visual.

- Anak autis tidak dapat memahami media audio visual yang banyak beradar.

Kebutuhan: Media audio visual yang dapat dipahami oleh anak autis.

Solusi yang ditawarkan penulis: Media audio visual dirancangan sesuai dengan kemampuan paham anak autis menggunakan lagu \& materi belajar yang disesuaikan untuk anak autis.

- Guru harus mengulang perintah berkali-kali supaya murid menjadi lebih fokus dan paham.

Kebutuhan: Media yang dapat membantu guru untuk mengulang perintah dalam pembelajaran.

Solusi yang ditawarkan penulis: Media pembelajaran yang memiliki fitur pengulangan suara untuk memudahkan guru dalam mengajar.

- Anak autis tidak tertarik dan susah terfokus dengan media visual berupa foto

Kebutuhan: Media visual yang menarik dan memudahkan fokus bagi anak autis.

Solusi yang ditawarkan penulis: Media visual menggunakan gaya gambar kartun. 
- Materi pembelajaran untuk anak autis khusus

Kebutuhan: Media pembelajaran yang mengandung materi khusus anak autis.

Solusi yang ditawarkan penulis: Dalam media pembelajaran berisi materi khusus anak autis.

Solusi dari kebutuhan - kebutuhan tersebut akan menjadi kriteria dalam penentuan konsep desain. Berdasarkan hasil dari breakdown data hasil penelitian, dilakukan analisa. Hasil analisa tersebut dilakukan untuk menemukan nilai utama sebagai dasaran konsep desain media pembelajaran anak autis. Analisa dilakukan dengan pengelompokkan berdasarkan isu sejenis. Setelah dilakukan pengelompokan berdasarkan isu sejenis, maka terdapat 2 nilai utama yang dihasilkan, yaitu Interesting \& Engaging, dan Compatible for Child with ASD dapat dilihat pada Gambar 2.

1) Interesting \& Engaging

Aplikasi android dilengkapi konten/fitur yang dapat merangsang feedback siswa (anak autis). Dengan adanya interaksi berupa sentuhan dan suara dapat membuat anak autis tertarik dan menjadi lebih mudah dalam mengingat dan memahami.

\section{2) Compatible for Child with ASD}

Anak autis sulit untuk terfokus dan konsentrasi, hal tersebut menyebabkan sulitnya pemahaman akan suatu konsep. Oleh karena itu, fitur yang terdapat pada aplikasi harus mudah dipahami oleh anak autis, baik secara visual, materi/konten dan suara.

\section{KONSEP DESAIN}

Pengambilan keputusan konsep desain pada perancangan ini adalah dengan menghubungkan kebutuhan dan keinginan yang telah diperoleh melalui hasil wawancara kepada stakeholder yaitu guru SLB Autisme, karena mereka merupakan pihak yang terkait dengan pemasalahan yang diangkat, serta user testing berupa uji coba desain aplikasi kepada target audiens yaitu anak autis dengan pendampingan dari guru SLB. Selain itu juga berdasar pada pada studi literatur yang telah ditinjau oleh penulis sebelumnya.

\section{A. Konsep Aplikasi}

Berdasarkan permasalahan, big idea, dan keyword dari perancangan ini, diperlukan judul atau nama dari aplikasi media pembelajaran untuk anak autis yang dapat menggambarkan karakter media pembelajaran yang menyenangkan, menarik dan efektif.

"Sekarang Aku Tahu" adalah kesimpulan dari big idea dan keyword dan menggambarkan siswa anak autis dalam melakukan proses kegiatan belajar. Kebutuhan pembelajaran anak autis yang lebih mengarah kepada pengetahuan kognitif dan rekognisi sangat terwakilkan dengan nama ini. Penggunaan bahasa Indonesia bertujuan agar nama aplikasi mudah diingat dan dilafalkan.

\section{B. Arsitektur Informasi}

Untuk merancang alur pengalaman pengguna pada aplikasi, arsitektur informasi diperlukan sebagai acuan dalam membuat halaman dan navigasi dapat dilihat pada Gambar 3.

\section{Spesifikasi Aplikasi}

Sistem operasi aplikasi Android, Perangkat yang disarankan Tablet, dengan resolusi layar 1280 x 800 px.

\section{Wireframe}

Konsep aplikasi digambar melalui visual sederhana yang mewakili keseluruhan aplikasi, yaitu wireframe. Wireframe akan menjadi acuan dalam penataan elemen desain antarmuka aplikasi. Pembuatan wireframe merupakan pengembangan arsitektur informasi menjadi beberapa tampilan halaman yang dapat dilihat pada Gambar 4.

\section{E. Desain Antarmuka}

1) Warna

Warna dalam keseluruhan aplikasi ditentukan dari hasil analisa data primer dan sekunder oleh penulis. Dari hasil analisa tersebut didapatkan warna yang digunakan adalah warna yang sederhana dan lembut. Penggunaan warna tersebut disesuaikan dengan kebutuhan anak autis dalam memproses informasi visual.

\section{2) Tipografi}

Tipografi yang digunakan dalam aplikasi berdasarkan pada kriteria desain visual font yang digunakan harus readable, clear, dan legible. Font jenis san serif, font reguler san serif untuk deskripsi suatu hal[7]. Font dengan ujung yang sedikit rounded khas aplikasi. Sehingga font yang digunakan adalah Avenir seri Next Rounded.

3) Ikon

Ikon produk dari aplikasi "Sekarang Aku Tahu" menggunakan logo primer dari aplikasi. Logo ini dimaksudkan untuk memudahkan guru dalam mengingat aplikasi dan memudahkan awareness terhadap aplikasi. Warna yang dipilih adalah warna cerah yang mencolok dikarenakan tujuan utama logo ini adalah menonjolkan aplikasi sehingga mudah dikenali dan diingat. Bentuk ikon dipilih dengan bentuk persegi bulat atau squircle dikarenakan penggunaannya yang fleksibel dalam beberapa macam versi Android dan terlihat lebih sederhana dapat dilihat pada Gambar 5.

4) Ikon Tombol

Ikon tombol yang digunakan pada desain antarmuka aplikasi menggunakan dasar bentukan geometris pada beberapa fungsi seperti tentang, play, pause, dan skip. Sedangkan untuk tombol mulai, kembali, dan putar ulang menggunakan tombol dengan teks. Hal tersebut dilakukan dengan alasan memudahkan penggunaan aplikasi sesederhana mungkin dan bertujuan agar pengguna dapat menjalankan aplikasi dengan mudah. Bentuk tersebut dieksplorasi dalam beberapa gaya dan dipilih salah satunya untuk menjadi gaya tombol dapat dilihat pada Gambar 6. 


\section{IMPLEMENTASI DESAIN}

\section{A. Implementasi Tipografi}

Desain akhir aplikasi menggunakan jenis font Avenir seri Next Rounded dengan ukuran yang disesuaikan dengan kebutuhan tampilan aplikasi Gambar 7.

\section{B. Hasil Desain Akhir}

Hasil akhir dari perancangan ini adalah berupa aplikasi dengan platform android. Desain dieksekusi dengan navigasi se-sederhana dan se-intuitif mungkin. Menimbang kepada pengguna yaitu guru SLB yang rata-rata merupakan generasi baby boomers yang mana sedikit susah memahami navigasi aplikasi jika terlalu banyak pilihan menu. Berikut ini adalah hasil dari implementasi elemen-elemen desain. Hasil desain akhir antarmuka aplikasi dapat dilihat dari sebelum membuka aplikasi hingga isi aplikasi itu sendiri. Hasil desain akhir dapat dilihat dalam bentuk mock up dapat dilihat pada Gambar 8 .

\section{Skenario Prosedur Penggunaan Media}

Setelah desain telah dieksekusi secara keseluruhan, dibuat panduan penggunaan media yang ditujukan kepada pengguna yaitu guru SLB dan murid autis di SLB. Panduan dibuat dengan tujuan agar pengguna dapat memahami bagaimana prosedur penggunaan media agar maksud dari perancangan dapat berfungsi secara maksimal. Berikut merupakan bagan penggunaan media dapat dilihat pada Gambar 9.

\section{Nilai Ketercapaian Media}

Ketercapaian media diambil berdasarkan perbandingan dengan media sebelumnya. Media sebelumnya terdiri dari buku bergambar dan flashcard. Indikator yang digunakan dalam pengujian ketercapaian media sebagaimana breakdown atau turunan pencapaian tujuan perancangan sebagai "penunjang proses belajar kognitif pada anak autis" adalah sebagai berikut:

1. Nilai ketertarikan anak autis dengan media

2. Nilai ketermotivasian anak autis dalam belajar dengan adanya media

3. Lama fokus pada anak autis dapat terjaga

4. Nilai kepahaman anak autis dengan isi materi yang disampaikan oleh media

5. Nilai pertambahan perkembangan kognitif (pengetahuan $\&$ pemahaman) pada anak autis dengan adanya media.

Berdasarkan indikator-indikator tersebut dibuatlah kuesioner yang ditujukan untuk 4 guru SLB berdasarkan pengamatan pada siswa didiknya ketika dihadapkan pada ketiga media sebagai tolak ukur keterpangaruhan tiap media dan nantinya dibadingkan.

Berikut merupakan hasil rata-rata dari penilaian 4 guru terhadap media buku bergambar dalam skala 1-10:

Berdasarkan hasil diatas didapati nilai rata-rata keseluruhan sebesar $27,6 \%$ dengan penggunaan media pembelajaran buku bergambar.

Berikut merupakan hasil penilaian 4 guru terhadap media flashcard dalam skala 1-10 yang dapat dilihat pada Tabel 1 3.
Berdasarkan hasil diatas didapati nilai rata-rata keseluruhan sebesar 39,8\% dengan penggunaan media pembelajaran flashcard.

Berikut merupakan hasil penilaian 4 guru terhadap media aplikasi dalam skala 1-10:

Berdasarkan hasil diatas didapati nilai rata-rata keseluruhan sebesar $66,7 \%$ dengan penggunaan media pembelajaran aplikasi.

Berdasarkan hasil perbandingan ketiga media diatas dapat disimpulkan penggunaan media aplikasi mendapatkan perbedaan yang cukup signifikan dibandingkan dengan media buku bergambar dan flashcard. Simpulan akhir dari pengujian nilai dan ketercapaian media adalah penggunaan aplikasi dapat dikatakan cukup efektif dengan indeks efektifitas 66,7\% dibandingkan dengan flashcard 39,8\% dan buku bergambar $27,6 \%$.

Pengujian aplikasi diatas merupakan sampling sederhana dalam pengujian media. Berdasarkan hasil wawancara dan hasil kajian penelitian sebelumnya, untuk mendapatkan hasil pengujian yang maksimal diperlukan waktu setidaknya 6 bulan dengan pemberian media secara rutin.

\section{KESIMPULAN DAN SARAN}

\section{A. Kesimpulan}

Siswa autis di SLB memiliki cara belajar yang berbeda dengan anak normal, salah satunya adalah dalam kegiatan belajar pada anak autis di SLB dilakukan menggunakan media pembelajaran berupa flashcard dengan pelafalan secara berulang-ulang oleh guru. Pengajaran juga dilakukan secara rutin dan monoton hingga anak autis memahami dan dapat mengucapkan nama benda yang tercantum pada flashcard tersebut. Kekurangan yang ada dalam media pembelajaran tersebut adalah fokus pada anak autis cenderung mudah teralihkan dikarenakan kurang menarik dan kurang memusatkan perhatian anak autis yang menyebabkan proses belajar anak autis menjadi kurang efektif dan cenderung lambat.

Dalam tugas akhir ini penulis merancang media pembelajaran yang mengandung kebutuhan belajar anak autis mulai dari kurikulum hingga cara belajar. Setelah dilakukannya uji coba pemakai menggunakan luaran dari perancangan ini didapatkan hasil bahwa fokus pada anak autis lebih dapat terkendali dan tidak mudah teralihkan. Dengan aplikasi hasil luaran perancangan ini diharapkan efektivitas proses belajar kognitif terhadap anak autis dapat meningkat.

\section{B. Saran}

Di dalam media pembelajaran berbasis aplikasi ini masih terdapat kekurangan yang belum sepenuhnya memenuhi kebutuhan kegiatan belajar pada anak autis di SLB. Beberapa kekurangan tersebut adalah belum terdapat keseluruhan materi pembelajaran anak autis, desain antarmuka aplikasi yang belum fleksibel dengan beberapa jenis resolusi tablet, dan pengujian efektivitas secara mendalam terhadap anak autis di SLB. Berikut adalah hal yang dapat dilakukan untuk 
mengembangkan perancangan ini:

1. Dilakukan uji coba efektivitas media pembelajaran terhadap anak autis secara rutin dan seksama dalam jangka waktu tertentu agar didapatkan hasil yang valid dan maksimal.

2. Dilakukan observasi dan analisa kebutuhan belajar anak autis lebih mendalam agar pengembangan aplikasi dapat dilakukan lebih rinci dan dapat menghasilkan media pembelajaran yang optimal dan sesuai dengan kebutuhan anak autis secara berlanjut.

3. Dilakukan penambahan fitur aplikasi yang disesuaikan dengan materi pembelajaran seperti indikator pembelajaran mencocokan benda. Dirancang gamifikasi drag and drop untuk menjadikan aplikasi menjadi lebih optimal dalam melakukan perannya sebagai media pembelajaran.

4. Bekerjasama dengan pakar autisme, ahli pemrograman aplikasi, animator dan ilustrator untuk membuat aplikasi yang siap disebarluaskan pada SLB autisme kendati meningkatkan kualitas pembelajaran.

5. Mengurus izin dan mengkaji metode pembelajaran kepada pihak-pihak berkepentingan seperti Kementrian Pendidikan dan Kebudayaan.

\section{DAFTAR PUSTAKA}

[1] Kementrian Pendidikan dan Kebudayaan Republik Indonesia, "Statistik sekolah luar biasa (SLB) 2016/2017," Jakarta, 2017.

[2] D. R. Desiningrum, Psikologi Anak Berkebutuhan Khusus. Yogyakarta: Psikosain, 2016

[3] D. R. Tambunan and A. Matulessy, "Pengaruh terapi bermain flashcard untuk meningkatkan interaksi sosial pada anak autis di miracle centre surabaya," Pers. J. Psikol. Indones., vol. 4, no. 1, pp. 51-60, 2015.

[4] D. M. Luterman and M. Ross, When Your Child Is Deaf: A Guide for Parents. Parkton, Maryland: York Press, 1991.

[5] S. Fletcher-Watson, H. Pain, S. Hammond, A. Humphry, and $\mathrm{H}$. McConachie, "Designing for young children with autism spectrum disorder: A case study of an iPad app," Int. J. Child-Computer Interact., vol. 7, pp. 1-14, 2016.

[6] N. Pavlov, "User interface for people with autism spectrum disorders," $J$. Softw. Eng. Appl., vol. 7, no. 2, pp. 128-134, 2014.

[7] K. Retaskie, "Parents perceptions of autism spectrum disorder," Master of Social Work Clinical Research Papers, St. Paul, Minnesota, May2015. 